\title{
Doğrudan veya Dolaylı Beslenme Eğitimi Verilen Çocukların Beslenme Bilgi Düzeylerinin Karşılaştırılması
}

\section{Comparison of the Nutritional Knowledge Levels of Children Given Direct or Indirect Nutrition Education}

\author{
Burcu Ateş Özcan ${ }^{1}$, Burcu Uslu ${ }^{2}$, Aydan Ercan $^{3}$
}

Geliş tarihi/Received: 14.04.2019 • Kabul tarihi/Accepted: 10.08.2019

\section{ÖZET}

Amaç: Bu araştırma, doğrudan ve dolaylı olarak ilkokul çocuklarına verilen beslenme eğitiminin, beslenme bilgi düzeyine etkisini karşılaştırmak amacıyla planlanmış ve yürütülmüştür.

Bireyler ve Yöntem: Çalışma Okan Koleji İlkokulu’nda 2017-2018 eğitim öğretim döneminde eğitim gören tüm ikinci ve üçüncü sınıf öğrencileriyle ( $n=70)$ yürütülmüştür. Çalışma öncesi sınıflar rastgele iki gruba ayrılmıştır: (1) doğrudan beslenme eğitimi verilen grup (DE: 2A ve 3A sınıfları), (2) dolaylı beslenme eğitimi verilen grup (ÖE: 2B ve 3B sınıfları). Çalışmanın birinci aşamasında ÖE grubundaki öğretmenlere, bir hafta arayla toplamda iki kez, 70 dakika süren beslenme eğitimleri verilmiştir. Eğitim alan öğretmenler kendi sınıflarında konuyla ilgili derslerde 4 hafta süresince (35 dakika/hafta, toplam 140 dakika) sağlıklı beslenme eğitimi vererek dolaylı beslenme eğitimini tamamlamıştır. DE grubundaki öğrencilere ise 4 hafta süresince toplam 140 dakika süren beslenme eğitimi araştırmacı tarafından doğrudan verilmiştir. Eğitim öncesinde öğrencilere demografik özelliklerini içeren anket formu, besin tüketim sıklık formu ve beslenme bilgi testi uygulanmıştır. Beslenme eğitimi ile verilen bilgilerin özümsenmesi ve davranışa dönüştürülmesi amacıyla 2 aylık ara sonrası öğrencilere besin tüketim sıklığı ve beslenme bilgi düzeyi anket formları tekrar uygulanmıştır.

Bulgular: Eğitim sonunda, eğitim yöntemi farkı olmaksızın tüm öğrencilerin beslenme bilgi puan ortalamaları artmış olsa da beslenme bilgileri orta düzeyde kalmıştır. Doğrudan beslenme eğitimi verilen öğrencilerin ortalama beslenme bilgi puanı düşük düzeyden orta bilgi düzeyine ( $<<0.05)$, dolaylı beslenme eğitimi verilen öğrencilerin ise orta düzeyden yüksek bilgi düzeyine yükselmiştir ( $\mathrm{p}<0.05)$.

Sonuç: Beslenme eğitiminde kullanılan her iki eğitim şeklinin de çocukların beslenme bilgi düzeylerini olumlu yönde etkilediği görülmüştür. Eğitim sonunda, dolaylı verilen eğitimde daha yüksek bilgi düzeyine sahip öğrenci sayısının fazla olması, başlangıçtaki bilgi düzeylerinin daha yüksek olmasından kaynaklı olabilir.

Anahtar kelimeler: Doğrudan beslenme eğitimi, dolaylı beslenme eğitimi, beslenme bilgisi, çocuk beslenmesi

1. İletişim/Correspondence: İstanbul Okan Üniversitesi, Sağllk Bilimleri Fakültesi, Beslenme ve Diyetetik Bölümü, İstanbul, Türkiye

E-posta: burcuates474@hotmail.com • ๑ https://orcid.org/0000-0003-2627-0167
2. İstanbul Okan Üniversitesi, Sağllk Bilimleri Fakültesi, Beslenme ve Diyetetik Bölümü, İstanbul, Türkiye (1) https://orcid.org/0000-0002-6371-6562

3. Trakya Üniversitesi, Sağlık Bilimleri Fakültesi, Beslenme ve Diyetetik Bölümü, Edirne, Türkiye

(ㄱ) https://orcid.org/0000-0003-1132-3908 


\section{ABSTRACT}

Aim: Study was planned and conducted to compare the nutritional knowledge levels of children who received either a direct or indirect nutrition education.

Subjects and Method: The study enrolled all second and third grade students, two classes for each, in Okan College Primary School during the 2017-2018 terms. Classes were randomly divided into two groups as: (1) direct nutrition education group (DE: 2A and 3A classes), (2) indirect nutrition education group (IE: 2B and 3B classes). During the first stage of the study, teachers in the IE group were given 70 minutes nutrition education for two times with one week interval. The teachers in the same group completed the study by giving nutrition education to their students for 4 weeks (35 minutes/week, 140 minutes in total). In DE group, the students received nutrition education directly from the researchers for a total of 140 minutes during 4 weeks. A questionnaire including demographics, food frequency and nutritional knowledge test were applied at baseline. Food frequency and nutritional knowledge questionnaires were repeated at 2 months after intervention to show the efficacy of nutrition education on dietary behaviors of students.

Results: At 2 months after intervention, there was an increase in mean scores of nutritional knowledge of all students regardless of education models however the level of nutritional knowledge remained at moderate in both groups. Nutritional knowledge level increased from low to medium in DE group ( $p<0.05)$, and medium to high in IE group ( $p<0.05)$.

Conclusion: Both nutrition education models used in this study had a positive effect on nutritional knowledge levels of children. The higher nutritional knowledge mean scores in indirect nutrition education model at the end of intervention may partly be explained by higher level of nutritional knowledge level at baseline.

Keywords: Direct nutrition education, indirect nutrition education, nutritional knowledge, child nutrition

\section{GİRIŞ}

Sağlıklı besinlerle, yeterli ve dengeli beslenme örüntüsü tüm canlılar için yaşamsal bir gerekliliktir (1). Hızlı bir büyüme ve gelişme sürecinin yaşandığı özellikle bebeklik, çocukluk ve adölesan çağı dönemlerinde besin ögelerine olan gereksinimlerin artması besin seçimi ve kullanımına da ayrı bir önem yüklemektedir. Yaşam boyu sürdürülen besin seçimi ve beslenme alışkanlıklarının çocuğa bu dönemlerde kazandırılması öncelikli bir gereklilik olarak kabul edilmektedir (2,3). Bireyin fiziksel ve zihinsel olarak hızlabüyüyüp geliştiğiokulçağı dönemi sosyalkimliğin kazanıldığı ve akademik olarak bilgi birikiminin yapıldığı bir dönemdir. Ayrıca bu dönemde yoğun psikolojik sorunlar gözlenebilmektedir. Dolayısıyla, bu dönemde yeterli ve dengeli beslenme ayrı bir önem kazanmaktadır. Bu dönemde çocukların kötü beslenme alışkanlıklarına sahip olmaları, zayıflı, şişmanlık, vitamin ve mineral yetersizliği ile ilişkili pek çok hastalıklar, yeme davranış bozukluğu ve diş çürükleri gibi bazı sorunların yanı sıra bilişsel kapasitede azalma, okul başarısının düşmesi gibi sonuçlara da neden olmaktadır (4).

Öğrenme hızının en üst düzeyde olduğu çocukluk döneminde ebeveyn ve öğretmenler çocuk için rol model olmakta, bu durum aile ortamının çocuğun gelişiminde önemli etkiye sahip olduğu bir dönem olarak kabul edilmektedir. Okul çağı çocuklarına verilen her türlü eğitim daha etkili ve kalıcı olmakta, edinilen alışkanlıklar, tutum ve davranışlar yetişkinlikte de sürdürülmektedir. $\mathrm{Bu}$ nedenle beslenme ve sağlık eğitimlerinin erken yaşlarda başlatılmasının, daha etkili ve kalıcı alışkanlıkların kazandırılmasında önemli olduğu vurgulanmaktadır (5-7).

Çocukların sağlıklı beslenme alışkanlıkları kazanmasında ebeveynlerden sonra en büyük görev öğretmenlere düşmektedir. Bu konuya önem veren okul yönetimleri ve öğretmenler sayesinde sağlıklı beslenen, daha sağlıklı çocuklar yetiştirmek mümkün 
olacaktır (8). Çocuk, okul çağına geldiğinde ailenin etkisi azalırken çevre ve diğer faktörler çocuğun yaşamında yer almaya başlamaktadır. İlk kez bilinçli olarak toplum yaşamına giren çocuk, kendine özgü tercihler yapmayı öğrenir (1). Beslenme bilinci bu yaşlarda oluşturulmadığında, çocuk hangi besini ne miktarda tüketeceğini bilemeyerek yanlış seçimler yapabilmekte, bu durum beslenme bozuklarının gelişimine zemin hazırlamaktadır $(9,10)$. Okullar yalnızca akademik başarıların gerçekleştirildiği öğretim kurumları olmayıp, bireyin toplum yararına yetiştirilmesinde, yaşam kalitesinin arttırılmasında, sağlığın korunup geliştirilmesinde en önemli kurumlar niteliğini taşımaktadır. $\mathrm{Bu}$ amaç doğrultusunda ilkokul, ortaokul ve liselerde verilen beslenme eğitimlerinin düzenli olması ve devamlılığının sağlanması verilen beslenme bilgilerinin davranışa geçebilmesinde en etkin yol olarak görülmektedir $(11,12)$.

$\mathrm{Bu}$ araştırmada, ilkokul 2. ve 3. sınıf öğrencilerine doğrudan ve dolaylı olarak verilen beslenme eğitiminin beslenme bilgi düzeylerine etkisini saptamak amacıyla planlanmış ve yürütülmüştür.

\section{BİREYLER VE YÖNTEM}

\section{Araştırma Yeri, Zamanı ve Örneklem Seçimi}

$\mathrm{Bu}$ çalışma için Başkent Üniversitesi Tıp ve Sağlık Bilimleri Araştırma Kurulu ve Girişimsel Olmayan Klinik Araştırmalar Etik Kurulu'ndan 03.01.2018 tarih ve 18/09 sayılı Etik Kurul Onayı alınmıştır. Daha sonra Okan Koleji İlkokul Müdürlüğü’nden gerekli izinler ve resmi yazı ile onay alınarak Ocak 2018-Nisan 2018 tarihleri arasında aynı okulun ilkokulunda eğitim gören tüm 2. sinıf ( 2 şube, $n=42$ ) ve 3 . sinıf ( 2 şube, $\mathrm{n}=30$ ) öğrencileri (toplam 4 şube, $n=72$ ) ile çalışma planlanmıştır. Her sınıfın kendi sınıf öğretmeni olup, 2. ve 3. sinıflar ile ilgilenen toplam 4 öğretmen bulunmaktadır.

Çalışmaya hastalığı sebebi ile okula gelemeyen ve 3. sınıfa devam eden iki öğrenci haricindeki tüm öğrenciler (n=70) dahil edilmiştir. Çalışmadan çıkarılan iki öğrencinin sınıf arkadaşlarından ayrı tutulmaması için bu öğrencilere de beslenme eğitimi verilmiş ve antropometrik ölçümleri alınmıştır ancak veriler çalışmaya dahil edilmemiştir.

Öğrencilerin ailelerine bilgi yazısı gönderilerek velileri tarafından çalışmaya katılması kabul edilen öğrenciler çalışmaya dahil edilmiş olup tüm veliler çalışmayı kabul etmiştir. Çalışmaya katılmayı kabul eden veliler "Veli Gönüllü Olur Onam Formu”nu, öğrenciler ise “Öğrenci Gönüllü Olur Onam Formu”nu okuyup imzalamıştır.

\section{Eğitimlerin Veriliş Şekli, Konusu ve İçeriği}

Okan Koleji İlkokulu'nda 2 şube 2. sinıf (2A, 2B) ve 2 şube 3. sınıf (3A, 3B) bulunmaktadır. Çalışma öncesi sınıflar rastgele iki gruba ayrılmıştır: (1) Doğrudan (araştırmacı tarafindan) beslenme eğitimi verilen grup (DE: 2A ve 3A sinıfları), (2) Dolaylı (öğretmen tarafından) beslenme eğitimi verilen grup (ÖE: 2B ve 3B sinıfları). “Doğrudan beslenme eğitimi”, araştırmacı tarafından 2A ve 3A sinıfları öğrencilerine doğrudan verilen beslenme eğitimi modelini tanımlamak için kullanılmıştır. Araştırmacı diyetisyen tarafından beslenme eğitimi alan 2B ve 3B sinıfı öğretmenlerinin, almış oldukları eğitimi kendi sınıflarına aktardıkları beslenme eğitimi modeli ise "dolaylı beslenme eğitimi” olarak tanımlanmıştır (Şekil 1). Araştırmacı tarafindan 2A ve 3A sinıfı öğretmenlerine beslenme eğitimi verilmemiş olup bu öğretmenler çalışmaya dahil edilmemiştir.

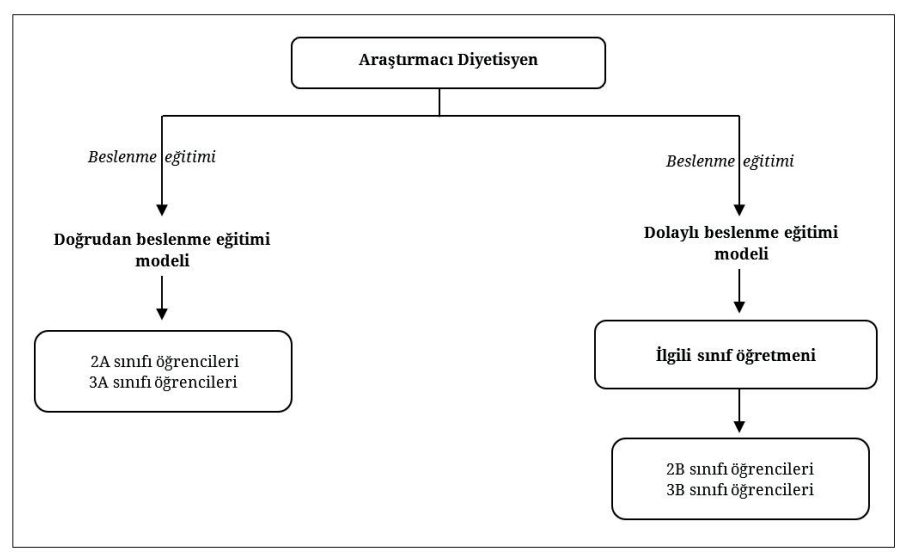

Şekil 1. Beslenme eğitimlerinin veriliş aşamaları ve beslenme eğitimi grupları 
Öğrenci eğitimleri başlamadan önce, araştırmacı tarafından 2B ve 3B sınıfı öğretmenlerine bir hafta arayla her biri 70 dakika olacak şekilde $2 \mathrm{kez}$ (toplam 140 dakika) beslenme eğitimi verilmiştir. Akabinde eş zamanlı öğrenci eğitimleri başlamıştır. Doğrudan beslenme eğitiminde araştırmacı tarafindan $2 \mathrm{~A}$ ve 3A sinıfı öğrencilerine 4 hafta süresince, 15 gün ara ile her biri 35 dakika (bir ders süresi) olacak şekilde 4 kez (toplam 140 dakika) bilgisayar destekli görsel sunum ile beslenme eğitimi verilmiştir. $\mathrm{Bu}$ sinıfların öğretmenleri eğitim süresince beslenme ve ilgili konularda öğrencilere herhangi bir bilgi aktarımında bulunmamıştır. Dolaylı beslenme eğitimi grubunda ise $2 \mathrm{~B}$ ve $3 \mathrm{~B}$ sinıflarının öğretmenleri, beslenme eğitimi sırasında almış oldukları beslenme bilgisini, "doğrudan verilen beslenme eğitimi" ile eş zamanlı olarak 4 hafta süresince "Hayat Bilgisi" ve "Fen Bilimleri" derslerine entegre ederek (her hafta bir ders süresi [35 dakika], toplamda 140 dakika) öğrencilerine aktarmıştır. Araştırmacının öğretmenlere ve öğrencilere vermiş olduğu beslenme eğitimlerinin içeriği aynıdır ve eğitim konuları aşağıda özetlenmiştir:

I. Sağlıklı Beslenme-1: Sağlıklı beslenmenin tanımı ve önemi, yeterli ve dengeli beslenme, besin grupları.

II. Sağlıklı Beslenme-2: Besin ögeleri ve sağlık için önemi, sağlıklı tabağım, besin seçimi ve günlük beslenme konuları.

III. Çocuklarda Sağlıklı Beslenme: Çocuk beslenmesinin önemi, büyüme ve gelişmedeki yeri, yetersizlik ve dengesizlik durumlarında karşılaşılan sorunlar, çocuklarda yeterli ve dengeli beslenme.

IV. Doğru bilinen yanlışlar ve sıkça sorulan sorular.

\section{Veri Toplama Araçları}

Eğitim öncesinde öğrencilerin tümüne, demografik bilgileri içeren bir anket formu ile besin tüketim sıklığı formu ve beslenme bilgi testi uygulanmıştır. Eğitim sonrasında verilen eğitimlerin özümsenmesi ve davranışa dönüştürülebilmesi için ön görülen 2 aylık bekleme süreci sonunda öğrencilere besin tüketim sıklığı ve beslenme bilgi düzeyi anket formları tekrar uygulanmıştır. Öğrencilere uygulanan tüm formlar araştırmacı tarafından yüz yüze görüşme yöntemi ile kaydedilmiştir.

Araştırmacı diyetisyen tarafından öğrencilere, tüketilen besinlerin sıklığı ve tüketim miktarlarının sorgulandığı 49 besin içeren bir besin tüketim sıklığı anketi uygulanmıştır. Alınan kayıtlar üzerinden öğrencilerin günlük diyetle aldıkları enerji ve besin ögeleri miktarı hesaplanmıştır. Bu veriler "Bilgisayar Destekli Beslenme Programı, Beslenme Bilgi Sistemleri Paket Programı (BeBiS, Versiyon 7.2)” kullanılarak analiz edilmiştir (13).

Araştırmacı tarafından, hem literatür taraması hem de öğretmenlerden alınan görüşler doğrultusunda, beslenme eğitimi süresince öğrencilere verilen beslenme bilgisi ile paralellik gösteren bir "Beslenme Bilgi Testi (BBT)” formu hazırlanmıştır (14-17). Bu form, beslenme eğitiminden önce ve eğitimden sonraki 2 aylık bekleme sürecinin sonunda olmak üzere toplamda 2 kez uygulanmıştır. Bu şekilde hem öğrencilerin eğitim öncesi ve sonrasındaki mevcut bilgi düzeyleri ölçülebilmiş, hem de eğitim sonrasında bilgi düzeylerinde meydana gelen değişim saptanmıştır. On sorudan oluşan BBT formunda her doğru soru 1 puan olarak belirlenmiş olup yanlış sorular puanlamayı etkilememiştir. Test toplam 10 puan üzerinden değerlendirilmiştir. Değerlendirme sonunda 4 puan ve altı “düşük”, 5-7 puan “orta”, 8-10 puan “yüksek” bilgi düzeyi olarak gruplandırılmıştır.

\section{Verilerin İstatistiksel Değerlendirmesi}

Sürekli veriler için merkezi limit teoremine göre gruplardaki sayılar yeterli olduğundan normal dağılım yaklaşımı altında analizler yapılmıştır (18). Buna göre bağımsız iki grup ortalaması karşılaştırmasında Student's t-test, bağımlı iki grup ortalaması karşılaştırmasında Paired t-test, bağımsız grupların zamana göre değişimini gözlemlemek için ise genel lineer modellerden tekrarlı ölçümlerde iki yönlü varyans analizi kullanılmıştır. Tanımlayıcı 
istatistikler ortalama, standart sapma $\left(\overline{\mathrm{X}}_{ \pm} \mathrm{SS}\right)$, alt ve üst değerler ile ifade edilmiştir. Kategorik verilerin analizinde bağımsız gruplarda Ki-Kare testi ve 5’ten küçük gözlem sayısının \%20’nin üzerinde olması durumunda Fisher Exact testi kullanılmıştır. İkiden fazla grubu olan bağımlı veriler için Marjinal homojenlik testi uygulanmıştır. Çalışmanın tanımlayıcı istatistikleri frekans (S) ve yüzde (\%) ile ifade edilmiş olup anlamlı ilişki bulunanlar için iki oran karşılaştırması yapılmıştır. Analizlerde anlamlılık seviyesi $\mathrm{p}<0.05$ olarak alınmıştır. Araştırma sonucunda elde edilen verilerin değerlendirilmesi. Analizler, SPSS (Statistical Package for Social Sciences, versiyon 21.0) programı kullanılarak yapılmıştır.

\section{BULGULAR}

Çalışmaya yaş ortalaması $8.2 \pm 0.7$ yıl olan, 32 (\%45.7) kız, 38 (\%54.3) erkek toplam 70 öğrenci katılmıştır. DE grubunun yaş ortalaması $8.1 \pm 0.6 \mathrm{yll}$, ÖE grubunun yaş ortalaması ise $8.3 \pm 0.8$ ylldır ( $p>0.05$ ). DE grubunun 15'i (\%46.9) kız, 17’si (\%53.1) erkek iken ÖE grubunun 17'si kız (\%44.7), 21'i (\%55.3) erkek öğrencilerden oluşmaktadır ( $\mathrm{p}>0.05$ ). Tablo 1'e göre çalışmaya katılan tüm öğrencilerin 42'si (\%60.0) 2. sinıf, 28'i (\%40.0) 3. sınıf öğrencilerden oluşmaktadır. Çalışmada 2 . ve 3. sınıf öğrencileri arasındaki fark istatistiksel olarak önemli bulunmamıştır ( $p>0.05)$.

ÖEgrubunun eğitim öncesi BBT puanının DEgrubunun eğitim öncesi BBT puanından daha yüksek olduğu görülmektedir $(p<0.05)$. BBT puanı eğitim sonunda tüm gruplarda yükselmiştir (Tablo 2) $(\mathrm{p}<0.001)$. Eğitim sonunda ÖE grubunun BBT puanı yüksek olup, fark istatistiksel olarak önemli bulunmuştur $(p<0.05)$. Beslenme bilgi testi puanlarının eğitim sonundaki artış oranları DE grubunda, ÖE grubuna göre daha fazla olup istatistiksel olarak önemli bulunmamıştır ( $>0.05)$.

Tablo 3'te öğrencilerin BBT puanları gruplandırıldığında, eğitim öncesi \%50'sinin ( $\mathrm{n}=35)$ düşük, \%27.1'inin (n=19) orta ve \%22.9'unun ( $n=16)$ yüksek bilgi düzeyine sahip oldukları belirlenmiştir. Eğitim sonunda ise öğrencilerin \%7.1'inin $(n=5)$ düşük, \%34.3’ünün ( $\mathrm{n}=24)$ orta ve \%58.6'sinın ( $\mathrm{n}=41)$ yüksek bilgi düzeyinde yer aldığı görülmüştür. Eğitim modeline göre öğrencilerin eğitim öncesi ve sonrasindaki ortalama beslenme bilgi testi puanlarının gruplar arası farkı istatistiksel olarak önemli bulunmuştur $(p<0.05)$. Eğitim öncesi ÖE grubunun \%42.1’i yüksek bilgi düzeyine sahipken DE grubunda yüksek bilgi düzeyinde öğrenci

Tablo 1. Öğrencilerin demografik özellikleri ve sınıf düzeyine göre dağılımı

\begin{tabular}{|c|c|c|c|c|}
\hline \multirow{2}{*}{ Özellik } & DE (n=32) & ÖE (n=38) & Toplam $(n=70)$ & \multirow[b]{2}{*}{$\mathbf{p}$} \\
\hline & $\overline{\mathrm{X}} \pm \mathrm{SS}$ & $\overline{\mathrm{X}} \pm \mathrm{SS}$ & $\overline{\mathrm{X}} \pm \mathbf{S S}$ & \\
\hline \multicolumn{5}{|l|}{ Yaş, yıl } \\
\hline $\mathrm{K} ı \mathrm{z}$ & $8.1 \pm 0.5$ & $8.2 \pm 0.0$ & $8.2 \pm 0.7$ & $0.66^{\mathrm{a}}$ \\
\hline Erkek & $8.0 \pm 0.6$ & $8.3 \pm 0.72$ & $8.2 \pm 0.7$ & $0.20^{\mathrm{a}}$ \\
\hline Toplam & $8.1 \pm 0.6$ & $8.3 \pm 0.8$ & $8.2 \pm 0.7$ & $0.21^{\mathrm{a}}$ \\
\hline \multirow[t]{2}{*}{$p$} & $0.645^{\mathrm{b}}$ & $0.627^{\mathrm{b}}$ & $0.065^{\mathrm{b}}$ & \\
\hline & S (\%) & S (\%) & S (\%) & \\
\hline \multicolumn{5}{|l|}{ Cinsiyet } \\
\hline $\mathrm{K} ı \mathrm{Z}$ & $15(46.9)$ & $17(44.7)$ & $32(45.7)$ & \multirow{2}{*}{$0.86^{\mathrm{a}}$} \\
\hline Erkek & $17(53.1)$ & $21(55.3)$ & $38(54.3)$ & \\
\hline \multicolumn{5}{|c|}{ Sinıf düzeyi } \\
\hline 2. sinif & 23 (71.9) & $19(50.0)$ & $42(60.0)$ & \multirow{2}{*}{$0.06^{\mathrm{a}}$} \\
\hline 3. sinif & $9(28.1)$ & $19(50.0)$ & $28(40.0)$ & \\
\hline
\end{tabular}

a: Ki Kare Test, $b$ : Student's $t$ Test

DE: Diyetisyen tarafindan doğrudan verilen beslenme eğitimi, ÖĞ: Araştırmacı tarafindan beslenme eğitimi almış öğretmenin öğrencilere verdiği dolaylı beslenme eğitimi. 
Tablo 2. Öğrencilerin eğitim şekillerine göre eğitim öncesi ve sonrasındaki beslenme bilgi testi puan ortalamaları

\begin{tabular}{|c|c|c|c|c|c|c|c|c|}
\hline \multirow{2}{*}{$\begin{array}{l}\text { Beslenme bilgi testi } \\
\text { puanı }\end{array}$} & \multicolumn{2}{|c|}{$\mathrm{DE}(\mathrm{n}=32)$} & \multicolumn{2}{|c|}{ ÖE (n=38) } & \multicolumn{2}{|c|}{ Toplam $(n=70)$} & \multirow[b]{2}{*}{$\mathbf{P}_{\mathrm{t}}$} & \multirow{2}{*}{$\mathbf{P}_{\text {GLM }}$} \\
\hline & $\overline{\mathrm{X}} \pm \mathbf{S S}$ & Alt-Üst & $\overline{\mathrm{X}} \pm$ SS & Alt-Üst & $\overline{\mathrm{X}} \pm$ SS & Alt-Üst & & \\
\hline$\overline{\text { Eğitim öncesi }}$ & $4.2 \pm 1.5$ & $2.0-7.0$ & $5.7 \pm 3.1$ & $1.0-10.0$ & $5.0 \pm 2.6$ & $1.0-10.0$ & $0.01^{*}$ & \multirow{2}{*}{0.619} \\
\hline Eğitim sonrası & $7.0 \pm 1.9$ & $4.0-10.0$ & $8.1 \pm 1.5$ & $5.0-10.0$ & $7.6 \pm 1.8$ & $4.0-10.0$ & $0.01^{*}$ & \\
\hline $\mathrm{P}_{\text {pair }}$ & \multicolumn{2}{|c|}{$<0.001^{* *}$} & \multicolumn{2}{|c|}{$0.001^{*}$} & \multicolumn{2}{|c|}{$<0.001^{* *}$} & & \\
\hline
\end{tabular}

$p_{\text {pair }}$ :Paired $t$ Test, $p_{t}$ : Student's $t$ Test, $p_{G L M}:$ Genel lineer modellerden (GLM) tekrarlı ölçümlerde iki yönlü varyans analizi (GL)

*: p<0.05, **: p<0.001, DE: Diyetisyen tarafindan doğrudan verilen beslenme eğitimi, ÖE: Araştırmacı tarafindan beslenme eğitimi almış öğretmenin öğrencilere verdiği dolaylı beslenme eğitimi

bulunmamaktadır. Eğitim sonunda ÖE grubunun \%65.8'inin, DE grubunun ise \%50.0'sinin yüksek bilgi düzeyine sahip olduğu saptanmıştır. Eğitim sonunda ÖE grubunda düşük bilgi düzeyine sahip öğrenci bulunmazken DE grubunda öğrencilerin \%15.6’sının düşük bilgi düzeyinde olduğu saptanmıştır. Eğitim sonunda gruplar arası BBT testi puanı arasındaki fark istatistiksel olarak önemli bulunmuştur $(\mathrm{p}<0.05)$.

Öğrencilerin beslenme eğitimi öncesi ve sonrası diyetle besin ögeleri alımı ile BBT puanları arasındaki ilişki incelenmiştir (Tablo 4). Eğitim öncesi BBT puanı ile riboflavin $(\mathrm{r}=0.380, \mathrm{p}=0.001)$, demir $(\mathrm{r}=0.274$, $\mathrm{p}=0.022)$ ve $\mathrm{B} 6$ vitamini $(\mathrm{r}=0.322, \mathrm{p}<0.001)$ alım düzeyleri arasında pozitif yönlü ve zayıf derecede ve niasin alım miktarı ile pozitif yönlü ve orta derecede doğrusal bir ilişki $(\mathrm{r}=0.450, \mathrm{p}<0.001)$ saptanmıştır. Bununla birlikte eğitim öncesinde BBT puanı ile kalsiyum alımı arasında negatif yönlü, zayıf derece $(r=-0.248, p=0.039)$ ve posa alımı ile negatif yönlü, orta derecede doğrusal bir ilişki olduğu belirlenmiştir ( $r=-$ 0.410, $\mathrm{p}<0.001$ ) (Tablo 4). Eğitim sonrası BBT puanları ve diyetle tiamin $(r=0.294, p=0.013), B 6 \quad(r=0.359$, $\mathrm{p}=0.002)$, $C$ vitamini $(r=0.309, p=0.009)$, demir $(r=0.384$, $\mathrm{p}=0.001)$, fosfor, $(\mathrm{r}=0.322, \mathrm{p}=0.007)$, magnezyum $(\mathrm{r}=0.352, \mathrm{p}=0.003)$ ve posa $(\mathrm{r}=0.363, \mathrm{p}=0.002)$ alımlar arasında pozitif yönlü, zayıf derecede doğrusal bir ilişki bulunmuştur. Eğitim sonrası BBT puanı ile günlük potasyum alımı arasında ise negatif yönlü, orta derecede doğrusal bir ilişki $(r=0.424, p<0.001)$ belirlenmiştir (Tablo 4).

\section{TARTIŞMA}

Besin ve beslenme bilgi düzeyi ile sağlıklı ve doğru beslenme alışkanlıkları arasında güçlü ilişki olduğu bilinmektedir. Çocuklarda beslenme eğitimi; beslenme bilgisi, beslenme davranışları ve yeme alışkanlıklarında önemli derecede olumlu gelişmeler sağlamaktadır (12,19). İlkokula giden 72 kız öğrenci ile yapılan bir çalışmada öğrenciler müdahale grubu ve kontrol grubu olmak üzere ikiyi ayrılmıştır (20). Müdahale grubuna 4 basamaklı beslenme eğitimi araştırmacı tarafindan doğrudan verilmiş olup kontrol grubuna herhangi bir eğitim verilmemiştir. Eğitim öncesi ve eğitimden 2 ay sonra tüm öğrencilere anket formları uygulanmıştır. Çalışma sonucunda beslenme eğitimi verilen grupta beslenme bilgisi, tutumu ve davranışlarının eğitim ile olumlu yönde geliştiği görülmüştür. Benzer olarak bu çalışmada da tüm grupların BBT puanlarının eğitim öncesine göre eğitim sonunda yükseldiği saptanmıştır $(p<0.05)$. Bu sonuç, öğrencilere verilen beslenme eğitimlerinin öğrenciler üzerinde etkili olduğunu göstermektedir. Eğitimler sonunda dolaylı verilen beslenme eğitimi grubunun BBT puanları doğrudan verilen beslenme eğitimi grubunun puanlarından daha yüksek bulunmuştur $(p<0.05)$. Ancak eğitim sonundaki BBT puanındaki yükselme oranlarının her iki grup için de benzer olduğu görülmüştür ( $p>0.05)$. Bu durum ÖE grubunda eğitim öncesi bilgi testi puanı yüksek olan öğrenciler olup, DE grubunda olmamasından kaynaklı görülebilir. Ayrıca, öğretmenler tarafından 

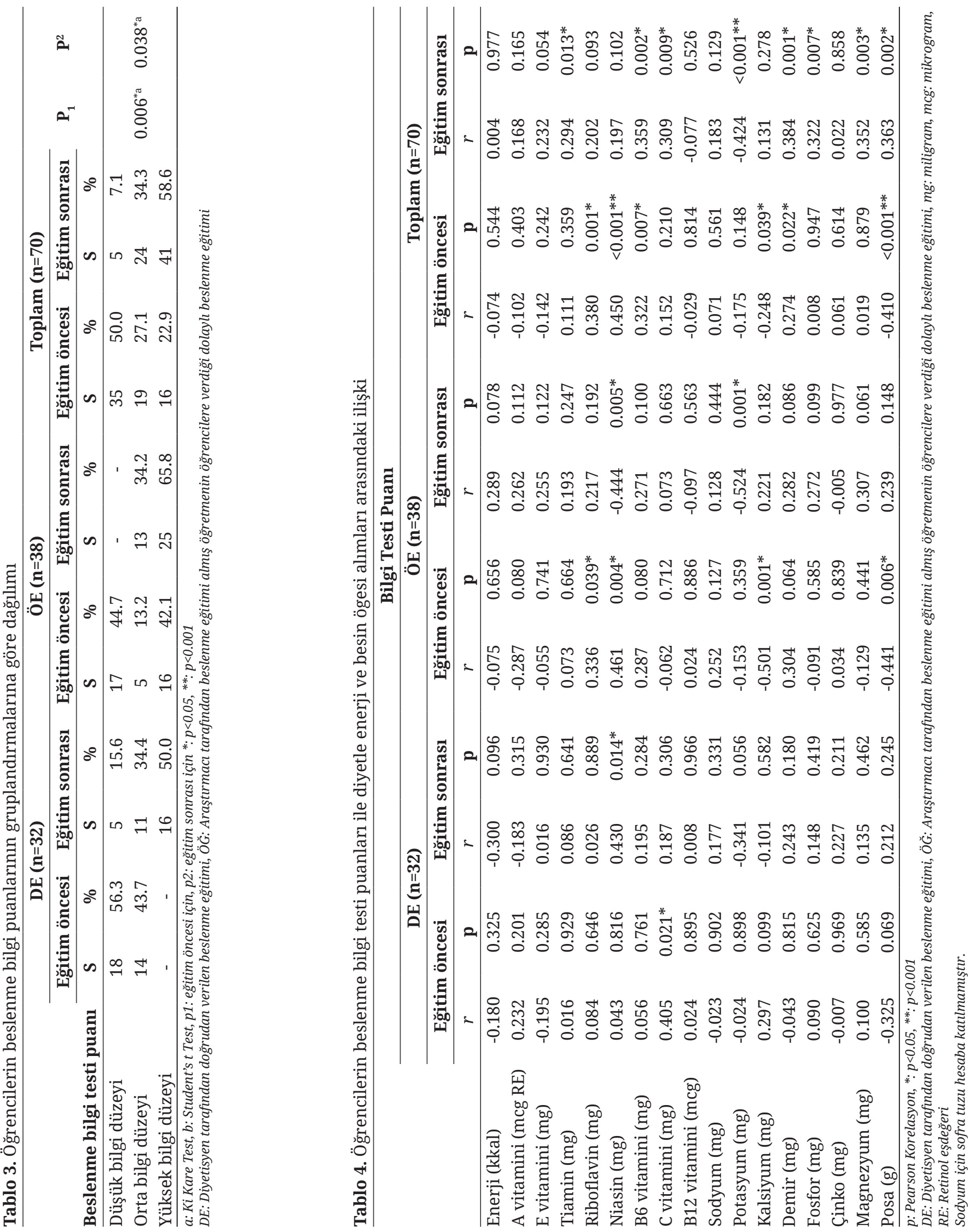
verilen dolaylı beslenme eğitiminde öğretmenler rol model olarak daha fazla dikkate alınmış olabilir. Hem genel örneklemde hem de doğrudan beslenme eğitimi verilen grupta BBT puan ortalamaları eğitim öncesi ve sonrasında orta düzey olarak saptanmış olmakla birlikte her iki grupta da BBT puan ortalamaları yükselmiştir. Dolaylı beslenme eğitimi verilen grupta ise eğitim öncesi beslenme bilgi düzeyi orta seviyedeyken eğitim sonunda yüksek bilgi düzeyine ulaşılmıştır. DE grubunda başlangıçta BBT puanı yüksek olan öğrenci bulunmamakla birlikte eğitim sonrası bu gruptaki öğrencilerin \%50'sinin BBT puanı 'yüksek' çıkmış, ancak sonuç istatistiksel olarak anlamlı bulunmamıştır ( $>0.05)$. Beslenme bilgi testi puanları, eğitimler sonunda dolayı beslenme eğitimi verilen grupta daha yüksek olsa da, puanların artış oranlarının benzer olması verilen eğitimlerin beslenme bilgisine etkisinin benzer olduğu sonucunu ortaya koymuştur.

Besinlerde bulunan temel besin ögelerinin her biri vücudun büyümesi ve gelişmesi, yıpranan dokuların onarımı, yaşamın sağlıklı ve verimli olarak sürdürülmesi gibi vücudun temel fizyolojik süreçlerinde işlev görmektedir. Bu sebeple özellikle çocukların günlük enerji ve besin ögelerini, gereksinimleri düzeyinde karşılaması büyük önem taşımaktadır (21-23). Beslenme eğitiminin diyetle enerji ve besin ögesi alımı üzerindeki etkinliğinin araştırıldığı bir çalışmada, toplam 40 öğrenciye beslenme eğitimi verilmiş ve öğrencilerin eğitim öncesi ve sonrası günlük enerji ve besin ögesi alım miktarları değerlendirilmiştir (24). Çalışmanın sonucunda hem kız hem erkek öğrencilerin beslenme bilgi düzeyinde istatistikselolarakönemlibir artış olduğu görülmüştür. Yine aynı çalışmada öğrencilerin eğitim öncesi enerji, protein, riboflavin, C vitamini, niasin, kalsiyum ve demir düzeylerinin önerilenin altında kaldığı; eğitim sonunda ise kalsiyum, A vitamini, enerji, yağ, protein ve niasin alım düzeylerinde artış olduğu bildirilmiştir. $\mathrm{Bu}$ çalışmada ise öğrencilerin bilgi puanlarındaki artışın yanı sıra eğitim sonunda öğrencilerin diyet ile aldıkları tiamin, $\mathrm{B}_{6}$ vitamini, $\mathrm{C}$ vitamini, demir, fosfor, magnezyum ve posa miktarlarının beslenme bilgi düzeyleri ile pozitif, potasyum ile negatif yönlü anlamlı bir ilişkiye sahip olduğu görülmüştür. $\mathrm{Bu}$ sonuçlar, öğrencilerin beslenme bilgi düzeyindeki artış ile beslenme durumunun da iyileştirilebileceğini desteklemektedir.

Sağlığın korunması ve geliştirilmesinde eğitim en önemli unsurlardan birisi olarak kabul edilmektedir. Özellikle sağlıkla çok yakından ilişkili olan beslenme eğitimine eğitim-öğretim ve sağlık hizmetlerinin her kademesinde yer verilmesi beslenme ile ilintili sağlık sorunlarının düzeltilmesinde temel koşullar arasında yer almaktadır.

$\mathrm{Bu}$ nedenle temel eğitim kurumlarında beslenme faaliyetlerinin yürütülmesi, eğitim öğretim programlarının beslenme konularını içermesi yeni nesillerin daha sağlıklı ve verimli olmalarına büyük katkı sağlayacaktır. Böylelikle toplumun genç bireylerinin bilişsel gelişimi ve akademik başarıları da artacaktır. Bu nedenle okul sağlığı programlarında yeterli ve dengeli beslenme eğitimlerine gereken önemin verilmesi çok yönlü faydalar sağlayacaktır.

Çalışmada uygulanan beslenme bilgi testi formunun, valide edilmiş geçerliği ve güvenirliğine bakılmış bir form olmaması çalışmanın sınırlılıkları arasında değerlendirilmektedir. Çalışma, her iki beslenme eğitimi yönteminin de öğrencilerin beslenme bilgi düzeylerine olumlu etkilerinin olduğuna ve bilgi artışı doğrultusunda öğrencilerin diyet ile aldıkları tiamin, B6 vitamini, $C$ vitamini, demir, fosfor, magnezyum ve posa alım miktarlarının artmasını sağladığına dikkat çekmektedir.

Çıkar çatışması - Conflict of interest: Yazarlar çıkar çatışması olmadığını beyan ederler. - The authors declare that they have no conflict of interest.

\section{KAYNAKLAR}

1. Baysal A. Beslenme. 18. Baskı. Ankara: Hatiboğlu Yayınları; 2018. s.566.

2. Köksal G, Gökmen Özel H. Çocukluk ve ergenlik döneminde obezite. 1. Baskı, Ankara, Sağlık Bakanlığı Yayın No: 729, 2012.

3. T.C. Sağlık Bakanlığı, Türkiye Halk Sağlığı Kurumu. 
Türkiye Beslenme Rehberi TÜBER 2015. Erişim: https:// dosyasb.saglik.gov.tr/Eklenti/10915,tuber-turkiyebeslenme-rehberipdf.pdf Erişim tarihi: 24 Mart 2019.

4. Erdem S, Gökmen Özel H, Çınar Z, Işıkhan SY. Farklı sosyoekonomik düzeye sahip çocuklarda ailenin beslenme tutum ve davranışlarının çocuğun beslenme durumuna etkisi. Bes Diy Derg. 2017;45(1):3-11.

5. Food Research and Action Center. National School Lunch Program: Trends and factors affecting student participation. Available at: http://frac.org/wp-content/ uploads/national_school_lunch_report_2015.pdf Accessed March 24th, 2019.

6. Carraways-Stage V, Henson SR, Dipper A, Spangler H, Ash SL, Goodell LS. Understanding the state of nutrition education in the head start classroom: a qualitative approach. J Health Educ. 2014;45(1):52-62.

7. Merdol T. Okul öncesi dönem eğitimi veren kişi ve kurumlar için beslenme eğitim rehberi. 2. Baskı. Ankara: Hatipoğlu Yayınları; 2012. s.171.

8. Oğuz Ş, Derin Önay D. Okul öncesi eğitim kurumlarına devam etmekte olan 60-72 aylık çocukların beslenme alışkanlıkları: Öğretmen görüşlerinin değerlendirilmesi. TÜBAV Bilim Dergisi. 2013;6(1):1-10.

9. Arlı M, Şanlıer N, Küçükkömürler S, Yaman M. Anne ve çocuk beslenmesi. 8. Baskı. Ankara: Pegem A Yayıncılık; 2017. s.233.

10. T.C. Sağlık Bakanlığı, Temel Sağlık Hizmetleri Genel Müdürlüğü. Türkiye'de Okul Çağı Çocuklarında (6-10 Yaş Grubu) Büyümenin İzlenmesi (TOÇBİ) Projesi Araştırma Raporu. Erişim: http://www.istanbulsaglik.gov.tr/w/sb/ halksag/belge/mevzuat/turkiye_okul_cocuk_6_10yas_ buyume_izlen_rap.pdf Erişim tarihi: 24 Mart 2019.

11. Carraway-Stage V, Hovland J, Showers C, Diaz S, Duffrin MW. Food-based science curriculum yields gains in nutrition knowledge. J Sch Health. 2015;85:231-40.

12. Ercan A, Yılmaz S, Altundağ N. Bir grup ilköğretim sınıf öğretmeninin beslenme bilgi düzeyi. DBHAD Uluslararası Hakemli Beslenme Araştırmaları Dergisi. 2014;1(2):1-12.

13. Beslenme Bilgi Sistemi (BEBİS) 4. versiyon, İstanbul, 2004. Veri bankaları: Bundeslebensmittelschlüssel (BLS) 2.3 ve USDA12. Erişim adresi: www.bebis-tr.com Erişim tarihi: 25 Mart 2019.
14. Aktaç Ş. Okul öncesi çağ çocuklar için aile katılımlı beslenme eğitim modelinin geliştirilmesi ve çocukların beslenme bilgi ve davranışları üzerine etkisinin değerlendirilmesi (Beslenme ve Diyetetik/Doktora tezi). Başkent Üniversitesi/Sağlık Bilimleri Enstitüsü, Ankara; 2016.

15. Göbel P. Ebeveynlere verilen beslenme eğitiminin çocukların besin seçimine etkileri (Beslenme ve Diyetetik/Doktora tezi). Başkent Üniversitesi/Sağlık Bilimleri Enstitüsü, Ankara; 2016.

16. Hall E. An evaluation and exploration of nutrition education in elementary schools (Human Sciences/ Doctoral thesis). University of Nebraska/ Nutrition and Health Sciences, Lincoln; 2015.

17. Roofe NL. The impact of nutrition and health education intervention on kindergarten students' nutrition and exercise knowledge (Family and Consumer Sciences/ Doctoral thesis). Iowa State University/Family and Consumer Sciences, Ames; 2010.

18. Norman G. Likert scales, levels of measurement and the "laws" of statistics. Adv Health Sci Educ Theory Pract. 2010;5(5):625-32.

19. Hayes D, Contento IR, Weekly C. Position of the Academy of Nutrition and Dietetics, Society for Nutrition Education and Behavior, and School Nutrition Association: Comprehensive nutrition programs and services in schools. J Acad Nutr Diet. 2018;118(5):913-9.

20. Vardanjani AE, Reisi M, Javadzade H, Pour ZG, Tavassoli E. The effect of nutrition education on knowledge, attitude and performance about junk food consumption among students of female primary schools. J Educ Health Promot. 2015;4:53-9.

21. Bartleman J. Infant and child nutrition. Medicine 2019;47(3):195-8.

22. Dudley DA, Cotton WG, Peralta LR. Teaching approaches and strategies that promote healthy eating in primary school children: a systematic review and meta-analysis. Int J Behav Nutr Phys Act. 2015;12(28):1-26.

23. Yabancı N. Okul Sağlı̆̆ı ve Beslenme Programları. TAF Prev Med Bull. 2011:10(3):361-8.

24. Kızıltan G. Başkent Üniversitesi yiyecek içecek işletmeciliği programına kayıtlı öğrencilerin beslenme bilgi düzeyi ve beslenme durumuna beslenme eğitiminin etkisi. Bes Diy Derg. 2000;29(2):34-41. 